\title{
Reservoir Characterization and Volumetric Analysis of "Lee" Field, Onshore Niger Delta, Using 3D Seismic and Well Log Data
}

\author{
ADIGWE, P; *INICHINBIA, S \\ Department of Physics, University of Port Harcourt, Choba, Port Harcourt, Nigeria \\ *Corresponding AuthorEmail: sonny.inichinbia@yahoo.com; Sonny.inichinbia@uniport.edu.ng
}

\begin{abstract}
Three dimensional (3D) seismic data, and a suite of four geophysical well logs from four wells located on the Lee field, Niger Delta were analyzed using Petrel software for the aim of reservoir characterization and volumetric analysis of the field. The objectives among others include identification and delineation of the reservoirs and estimating the petrophysical parameters from the well logs available, generating time and depth structure maps of horizons from the seismic section, and a volumetric analysis in order to estimate hydrocarbon in place. The method adopted involves petrophysical analysis, structural analysis, static modelling, and volumetric analysis. Detailed petrophysical analysis revealed three reservoirs. Average Reservoir parameters such as effective porosity $(0.17)$, gross thickness $(86 \mathrm{~m})$, hydrocarbon saturation $(0.42)$, permeability $(1215 \mathrm{mD})$ and net-to-gross $(0.79)$ were derived from petrophysical analysis. The three reservoirs were classified using average results of petrophysical parameters. And based on these results, Reservoir 1 is the most prolific while Reservoir 3 is the least prolific within Lee field. Fault and Horizon interpretations were done using Petrel software which culminated in delivery of 3D structural map of the reservoirs. Structural, stratigraphic and Petrophysical models were developed and then integrated to produce a high resolution static model for Reservoir 1 . The hydrocarbon in place shows that reservoir 1 is of appreciable thickness and areal extent. The volume of hydrocarbon originally in place was estimated to be $367,180,095.08$ barrels of oil.
\end{abstract}

DOI: https://dx.doi.org/10.4314/jasem.v23i12.16

Copyright: Copyright $(\mathbb{C} 2019$ Adigwe and Inichinbia. This is an open access article distributed under the Creative Commons Attribution License (CCL), which permits unrestricted use, distribution, and reproduction in any medium, provided the original work is properly cited.

Dates: Received: 30 November 2019; Revised: 20 December 2019; Accepted: 23 December 2019

Keywords: volumetric, petrophysical, fault, saturation, net-to-gross, permeability, horizon

Reservoir characterization is a very important step in exploration and development phases of a prospect and combines multi-disciplinary results of different analyses to reduce risk and enhance understanding of reservoirs. This involves the use of empirical formula to estimate the reservoir parameters such as volume of shale, Formation factor, porosity, water saturation, permeability, hydrocarbon saturation etc. Calculations of such reservoir parameters will help to determine if a reservoir is exploitable (Obiora et al., 2016; Stacy et al., 2010; Okwoli et al., 2015; Obiora et al., 2016; Shepherd, 2009). The objective of this study was to characterize the reservoirs and determine the hydrocarbon in place through detail volumetric analysis.

Location of the study area: Lee field is located within the onshore continental margin, south-south Niger Delta (Figure 1). It occupies an area enclosed by the geographical grids of latitude $4^{0} 37^{\prime} 27.704 \mathrm{~N}$ and longitude $6^{0} 17^{\prime} 55.002 \mathrm{E}$.

Geology of the Niger Delta: The Niger Delta is a Palaeogene to Recent, wave dominated delta situated on the Atlantic coast of Africa and extends throughout the Niger Delta Province (Klett et al., 1997; Short and
Stauble, 1967). It is one of the largest regressive deltas in the world and is considered a classical shale tectonic province. From the Eocene to Recent, the delta has prograded south-westwards, forming depobelts that represent the most active portion of the delta at each stage of its development (Doust and Omatsola, 1990).

Methodology: Following the approaches adopted by Inichinbia et al. (2014 a,b,c); Ulasi et al., (2013); Stacy et al., (2010); Okwoli et al., (2015); Obiora et al. (2016), suites of four geophysical well logs and 3D seismic data recorded at various locations within the Lee field were used for the study. The seismic data set comprises of both inline and crossline sections. Each well consist of the following well logs; gamma ray, spontaneous potential, calliper, density, neutron, sonic, and resistivity logs. Well headers, well deviations and checkshots were also provided. The well $\log$ data are in LAS and ASCII formats. Petrel software was employed for the Geological and Geophysical Interpretation. Microsoft office 2013 (Excel) was also used for some of the statistical computations. 1

The data quality check was performed on each set of well $\log$. After all quality checks have been completed, 
the well and seismic data were imported based on selection into the petrel explorer based on the well logs, well deviations, checkshot and 3D Seismic volume. Well header and log header information were provided in digital ASCII format. The well header contain the well name, surface location of the wells (2D-XY coordinate system), Kelly bushing (Kb), the top depth and bottom depth. The reservoirs are identified by using a combination of the gamma ray and resistivity log signatures. The resistivity log was used to infer the type of fluid in the reservoir. The gamma ray log, which detects natural radioactive emissions of rocks, was used to delineate reservoirs. In Niger Delta basin, the two predominant lithologies are sand and shale. The basic petrophysical parameters include volume of shale $\left(\mathrm{V}_{\mathrm{sh}}\right)$, porosity $(\emptyset)$, water saturation $\left(\mathrm{S}_{\mathrm{w}}\right)$, permeability $(\mathrm{k})$, hydrocarbon saturation $\left(\mathrm{S}_{\mathrm{h}}\right)$, irreducible water saturation $\left(\mathrm{S}_{\mathrm{wirr}}\right)$, formation factor (F), Net-to-Gross, and thickness of sand. Proper analysis of these parameters is very essential for proper reservoir development, management and planning.

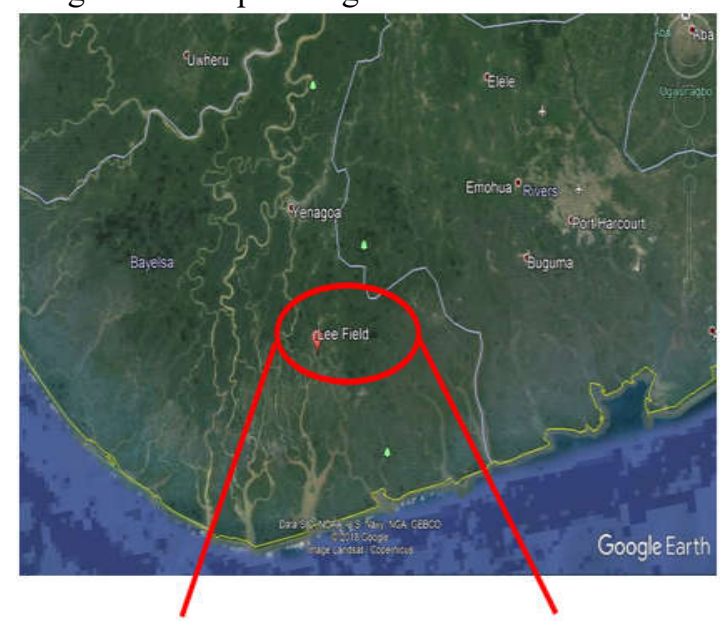

Fig.1a. Map of the study area showing the location of Lee field (source: Google earth pro, 2018).

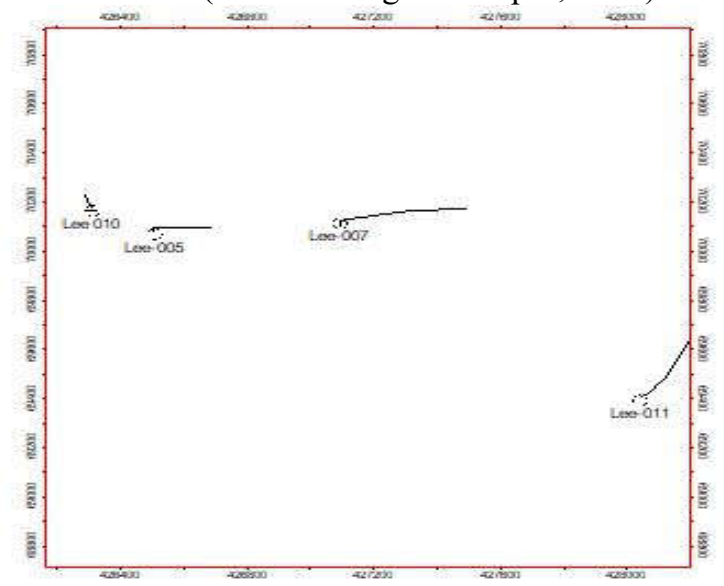

Fig $1 b$. The location map of Lee field showing the positions of the four wells drilled on the field

\section{RESULTS AND DISCUSSIONS}

Identification of prominent features such as major and minor faults was carried out on the seismic sections. The Faults were mapped in the inline direction. Seismic reflections which corresponded to top of main reservoir sands were identified on seismic data for mapping. The horizon mapped across both crossline and inline was used with fault polygon to generate time structure maps for the top and base of the three reservoirs. The available checkshot data were used for converting the time structural mapped to depth structural map. The checkshot data was utilized for Sand A reservoir in Lee field. The area extent of the reservoir was determined from the depth structural maps.

Permeable zones (sands) were differentiated from non-permeable zones using GR, SP and Neutron/Density logs. Based on this, tops and bases of Reservoir sands were delineated in all the four wells. Hydrocarbon-bearing intervals were discriminated from water-bearing intervals using the resistivity logs (especially deep resistivity).

Figure 2 shows the three reservoirs as seen in wells Lee 010, Lee 005, Lee 007 and Lee 011. Reservoir 1 occurs at depths $3751 \mathrm{~m}, 3720 \mathrm{~m}, 3756 \mathrm{~m}$ and $3801 \mathrm{~m}$ in Lee 010, Lee 005, Lee 007 and Lee 011 respectively. Reservoir 2 occurs at depths $3565 \mathrm{~m}$, $3533 \mathrm{~m}, 3494 \mathrm{~m}$ and $3526 \mathrm{~m}$ in Lee 010, Lee 005, Lee 007 and Lee 011 respectively. Reservoir 3 occurs at depths $3509 \mathrm{~m}, 3465 \mathrm{~m}, 3427 \mathrm{~m}$ and $3473 \mathrm{~m}$ in Lee 010, Lee 005, Lee 007 and Lee 011 respectively.

The analysis of all the well sections revealed that each of the sand units extended through the field and varies in thickness with some units occurring at greater depths than their adjacent units (i.e. possibly an evidence of faulting). The shale layers were observed to increase with depth with a corresponding decrease in sand layers. This pattern in the Niger Delta indicates transition from Benin to Agbada Formation (Amigun and Odole, 2013).

Table1shows the results of some computed petrophysical parameters for reservoir 1 (sand A) which cuts across Lee 010, 005, 007 and 011. The reservoir has a gross thickness ranging from $79 \mathrm{~m}$ to $107 \mathrm{~m}$, net thickness ranges from 71 to $88 \mathrm{~m}$ with a net/gross thickness (NTG) in the range of $84-92 \%$. The effective porosity, permeability, water saturation and hydrocarbon saturation of the reservoir are $14-21$ $\%, 933-1560 \mathrm{mD}, 20-81 \%$ and $19-80 \%$ respectively. 


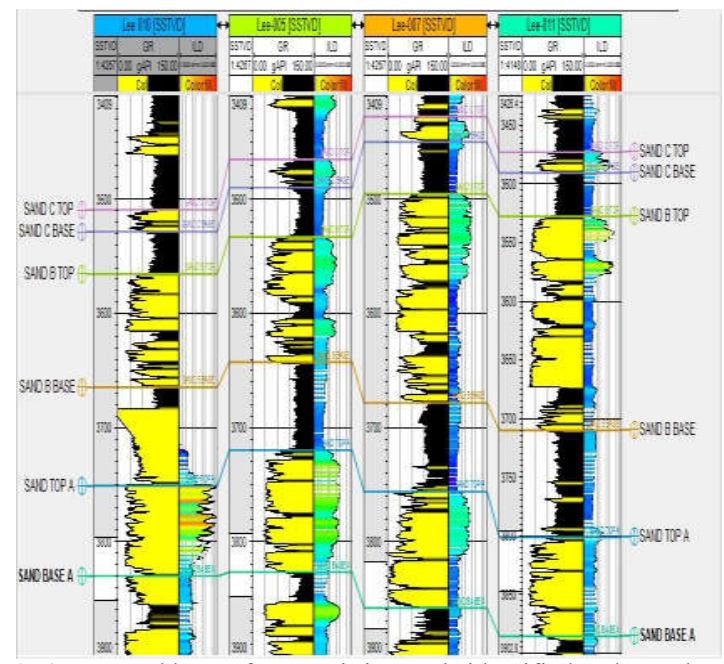

Fig 2. Top and base of reservoir intervals identified and correlated across the four wells. The sands extend through the field as evidenced by their presence in all the four wells on the field.

The porosity value of reservoir 1 as seen in the four wells is fair, while the high permeability value obtained in Lee 010 is excellent and permits the flow of fluid within the reservoir. The hydrocarbon saturation indicates that oil is higher than water within the reservoir. Hence reservoir 1 is oil and water bearing in Lee 007 , Lee 005 , heavily saturated with oil in Lee 011 and in Lee 010. The petrophysical parameters for reservoir 2 (sand B) are displayed in Table 2. This has a gross thickness ranging from 100 to $182 \mathrm{~m}$, net thickness ranges from 82 to $158 \mathrm{~m}$, net to gross ranges from 75 to $87 \%$, effective porosity ranges from 19 to 20 , the water saturation $\left(\mathrm{S}_{\mathrm{w}}\right)$ and hydrocarbon saturation $\left(\mathrm{S}_{\mathrm{h}}\right)$ ranges from $3 \%$ to $98 \%$, and $2 \%$ to $97 \%$. No data were available for permeability $(\mathrm{mD})$ in Lee 010 for this reservoir. The porosity values obtained from all the wells that penetrated reservoir 2 indicate a good to very good values. Furthermore, the values of permeability are excellent from three wells except for Lee 010 which does not have data for permeability. The ratio of the hydrocarbon to water saturation indicates that this reservoir contain both water and hydrocarbon, with that of water slightly higher than that of hydrocarbon saturation.

Table 1. Summary of the computed petrophysical parameters obtained for reservoir 1

\begin{tabular}{|c|c|c|c|c|c|c|c|c|c|c|c|c|}
\hline Wells & Top (m) & Base (m) & $\begin{array}{l}\text { Gross } \\
\text { thickness } \\
\text { (m) }\end{array}$ & $\begin{array}{l}\text { Shale } \\
\text { volume } \\
(\%)\end{array}$ & $\begin{array}{l}\text { Shale } \\
\text { volume } \\
\text { (m) }\end{array}$ & $\begin{array}{l}\text { Net sand } \\
\text { (m) }\end{array}$ & $\begin{array}{l}\text { Net to } \\
\text { Gross } \\
(\%)\end{array}$ & \begin{tabular}{|l|} 
Total \\
Porosity \\
$(\%)$
\end{tabular} & $\begin{array}{l}\text { Effective } \\
\text { Porosity } \\
(\%)\end{array}$ & \begin{tabular}{|l} 
Water \\
saturation \\
$(\%)$
\end{tabular} & \begin{tabular}{|l} 
hydrocar \\
bon \\
saturation \\
$(\%)$
\end{tabular} & $\begin{array}{l}\text { Permeabi } \\
\text { lity }(\mathrm{mD})\end{array}$ \\
\hline LEE 010 & 3751 & 3830 & 79 & 8 & 6.32 & 72.68 & 92 & 23 & 21 & 30 & 70 & 1560.44 \\
\hline LEE 005 & 3720 & 3827 & 107 & 18 & 19.26 & 87.74 & 82 & 21 & 17 & 44 & 56 & 1156 \\
\hline LEE 007 & 3756 & 3858 & 102 & 22 & 22.44 & 79.56 & 78 & 18 & 14 & 81 & 19 & 932.756 \\
\hline LEE 011 & 3801 & 3885 & 84 & 16 & 13.44 & 70.56 & 84 & 24 & 20 & 20 & 80 & 1518.35 \\
\hline
\end{tabular}

Table 2. Summary of the computed petrophysical parameters obtained for reservoir 2

\begin{tabular}{|c|c|c|c|c|c|c|c|c|c|c|c|c|}
\hline Wells & Top (m) & Base (m) & $\begin{array}{l}\text { Gross } \\
\text { thickness } \\
\text { (m) }\end{array}$ & $\begin{array}{l}\text { Shale } \\
\text { volume } \\
(\%)\end{array}$ & $\begin{array}{l}\text { Shale } \\
\text { volume } \\
\text { (m) }\end{array}$ & $\begin{array}{l}\text { Net sand } \\
(\mathrm{m})\end{array}$ & $\begin{array}{l}\text { Net to } \\
\text { Gross } \\
(\%)\end{array}$ & $\mid \begin{array}{l}\text { Total } \\
\text { Porosity } \\
(\%)\end{array}$ & $\begin{array}{l}\text { Effective } \\
\text { Porosity } \\
(\%)\end{array}$ & $\begin{array}{l}\text { Water } \\
\text { saturation } \\
(\%)\end{array}$ & \begin{tabular}{|l} 
hydrocar \\
bon \\
saturation \\
$(\%)$ \\
\end{tabular} & $\left\{\begin{array}{l}\text { Permeabi } \\
\text { lity }(\mathrm{mD})\end{array}\right.$ \\
\hline LEE 010 & 3565 & 3665 & 100 & 16 & 16 & 84 & 84 & 22 & 19 & 3 & 97 & \\
\hline LEE 005 & 3533 & 3642 & 109 & 25 & 27.25 & 81.75 & 75 & 22 & 17 & 66 & 34 & 1173.92 \\
\hline LEE 007 & 3494 & 3678 & 184 & 17 & 31.28 & 152.72 & 83 & 21 & 18 & 88 & 12 & 1265.79 \\
\hline LEE 011 & 3528 & 3710 & 182 & 13 & 23.66 & 158.34 & 87 & 23 & 20 & 98 & 2 & 1459.43 \\
\hline
\end{tabular}

Table 3. Summary of the computed petrophysical parameters obtained for reservoir 3

\begin{tabular}{|l|r|r|l|l|l|l|l|l|l|l|l|l|}
\hline Wells & Top $(\mathrm{m})$ & Base $(\mathrm{m})$ & $\begin{array}{l}\text { Gross } \\
\text { thickness } \\
(\mathrm{m})\end{array}$ & $\begin{array}{l}\text { Shale } \\
\text { volume } \\
(\%)\end{array}$ & $\begin{array}{l}\text { Shale } \\
\text { volume } \\
(\mathrm{m})\end{array}$ & $\begin{array}{l}\text { Net sand } \\
(\mathrm{m})\end{array}$ & $\begin{array}{l}\text { Net to } \\
\text { Gross } \\
(\%)\end{array}$ & $\begin{array}{l}\text { Total } \\
\text { Porosity } \\
(\%)\end{array}$ & $\begin{array}{l}\text { Effective } \\
\text { Porosity } \\
(\%)\end{array}$ & $\begin{array}{l}\text { Water } \\
\text { saturation } \\
(\%)\end{array}$ \\
\hline LEE 010 & 3509 & 3528 & 19 & 27 & 5.13 & 13.87 & 73 & 20 & 15 & 85 & 15 & $\begin{array}{l}\text { hydrocar } \\
\text { bon } \\
\text { saturation } \\
(\%)\end{array}$ \\
\hline LEE 005 & 3465 & 3489 & 24 & 43 & 10.32 & 13.68 & 57 & 20 & 11 & 95 & $\begin{array}{l}\text { Permeabi } \\
\text { lity }(\mathrm{mD})\end{array}$ \\
\hline LEE 007 & 3427 & 3450 & 23 & 19 & 4.37 & 18.63 & 81 & 24 & 20 & 39 & 661 & 1456.98 \\
\hline LEE 011 & 3473 & 3490 & 17 & 28 & 4.76 & 12.24 & 72 & 22 & 16 & 50 & 50 & 1034.06 \\
\hline
\end{tabular}




\begin{tabular}{|c|c|c|c|c|c|c|c|c|c|c|c|c|}
\hline Reservoirs & Top (m) & Base (m) & $\begin{array}{l}\text { Gross } \\
\text { thickness } \\
\text { (m) }\end{array}$ & $\begin{array}{l}\text { Shale } \\
\text { volume } \\
(\%)\end{array}$ & $\begin{array}{l}\text { Shale } \\
\text { volume } \\
(\mathrm{m})\end{array}$ & $\begin{array}{l}\text { Net sand } \\
\text { (m) }\end{array}$ & $\begin{array}{l}\text { Net to } \\
\text { Gross } \\
(\%)\end{array}$ & $\begin{array}{l}\text { Total } \\
\text { Porosity } \\
(\%)\end{array}$ & $\begin{array}{l}\text { Effective } \\
\text { Porosity } \\
(\%)\end{array}$ & $\begin{array}{l}\text { Water } \\
\text { saturation } \\
(\%)\end{array}$ & \begin{tabular}{|l|} 
hydrocar \\
bon \\
saturation \\
$(\%)$ \\
\end{tabular} & $\begin{array}{l}\text { Permeabi } \\
\text { lity }(\mathrm{mD})\end{array}$ \\
\hline Reservoirs 1 & 3757 & 3850 & 93 & 16 & 15.365 & 77.635 & 84 & 21.5 & 18 & 43.75 & 56.25 & 1291.89 \\
\hline Reservoirs 2 & 3530 & 3673.75 & 143.75 & 17.75 & 24.5475 & 119.203 & 82.25 & 22 & 18.5 & 63.75 & 36.25 & 1299.71 \\
\hline Reservoirs 3 & 3468.5 & 3489.25 & 20.75 & 29.25 & 6.145 & 14.605 & 70.75 & 21.5 & 15.5 & 67.25 & 32.75 & 1052.53 \\
\hline
\end{tabular}

Table 3 shows petrophysical parameters for reservoir 3 (sand C). This reservoir was penetrated by the four wells. This reservoir was penetrated between 3427 to $3528 \mathrm{~m}$ with gross thickness ranging from 17 to $24 \mathrm{~m}$, the net thickness is between 12-19 $\mathrm{m}$ and NTG 72 to $81 \%$. Reservoir 3 has porosity and permeability values ranging from 11 to $20 \%$ and 667 to $1457 \mathrm{mD}$ respectively. The water saturation $\left(\mathrm{S}_{\mathrm{w}}\right)$ ranges from 39 to $95 \%$, while the hydrocarbon saturation $\left(\mathrm{S}_{\mathrm{h}}\right)$ ranges from 5 to $61 \%$. The porosity values of reservoir 3 shows fair to very good values and the permeability value reveals a good interconnectivity between the pores. The water saturation and hydrocarbon saturation reveal that both hydrocarbon and water are present in the reservoirs with the water having a higher ratio. Hence reservoir 3 is an oil and water bearing unit. Table 4 shows the summary of the results of the important average petrophysical parameters utilized as variables that determine reservoir quality. These parameters are subjected to statistical analysis by considering their values across all the delineated reservoirs in the four wells of the study area and were used to rank the reservoir. Sequel to the analysis of the seismic data, the three reservoirs were classified using the results of average petrophysical parameters that have been computed (see Figures 3 - 5). And based on these, reservoir 1 is said to be most prolific while reservoir 3 is the least prolific in Lee field.

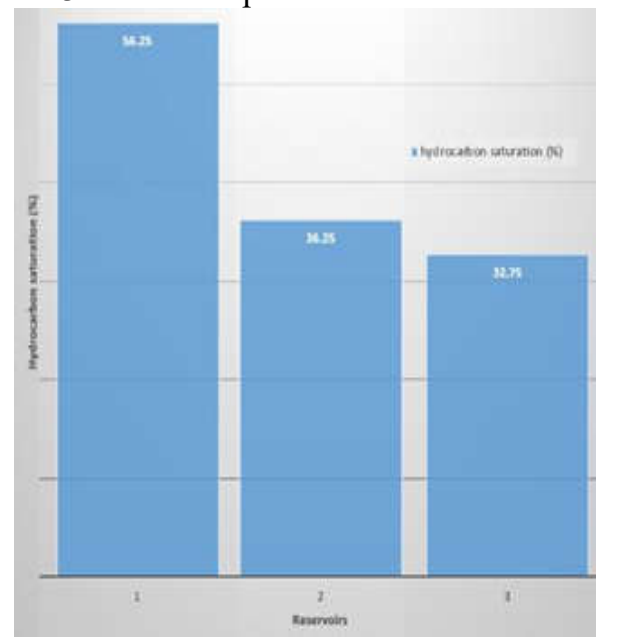

Fig 3. The reservoirs are ranked, using average hydrocarbon saturation values.

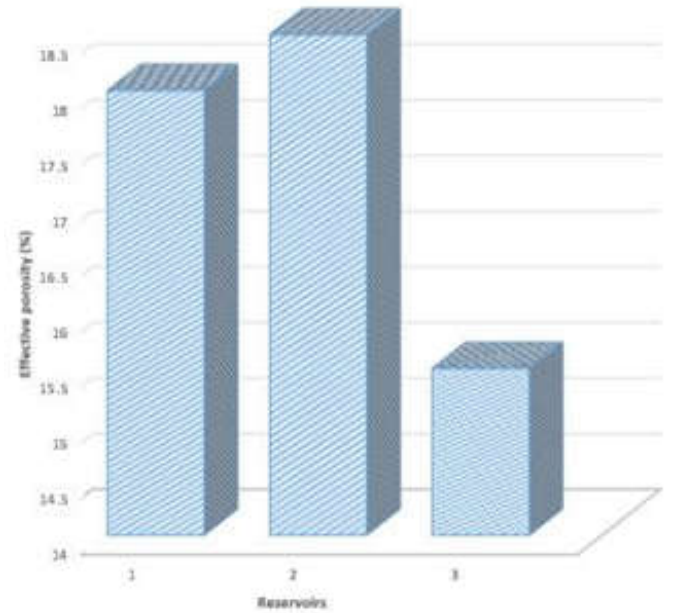

Fig 4. The reservoirs are ranked using average effective porosity values.

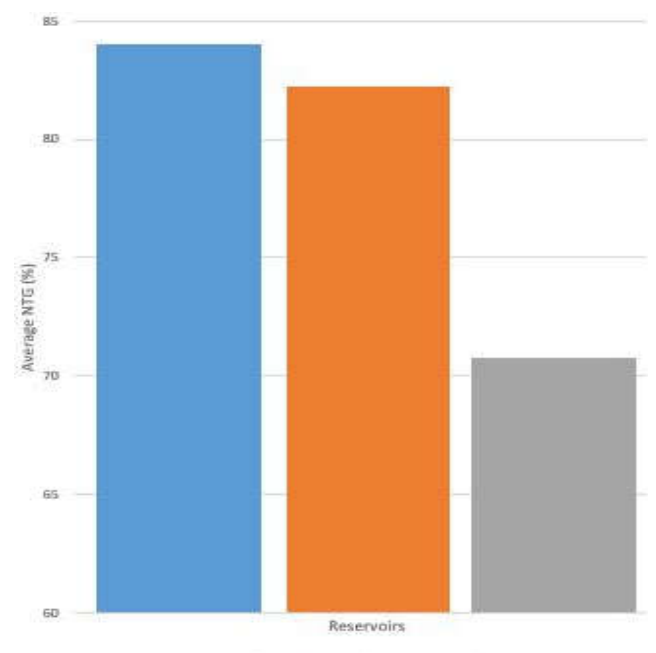

Fig 5. The reservoirs are ranked using average NTG values.

One horizon corresponding to the top and bottom of sand A, and six faults were mapped as horizon $1(\mathrm{H} 1)$ and fault 1 (F1), fault 2 (F2), fault 3 (F3), fault 4 (F4), fault 5 (F5) and fault 6 (F6) respectively across the seismic section as shown in Figure 6. Four (4) of the normal faults are NW-SE trending listric faults. These major faults show a soling out at the base of the section with a rollover anticlinal structure. The other two (2) are NE-SW trending antithetic faults. 


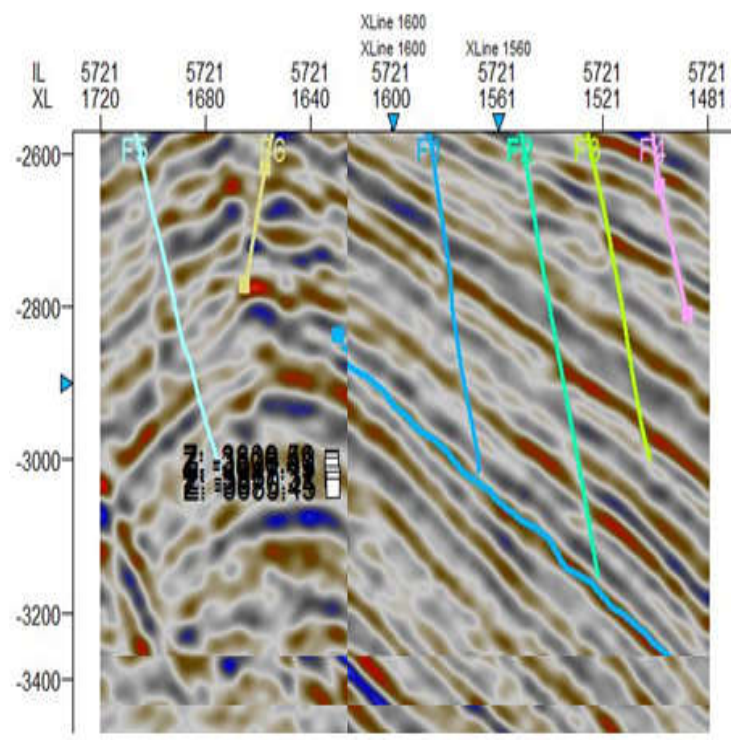

Fig 6. Inline 5721 showing the mapped faults and horizon

A synthetic seismogram generated for Lee 011 from the sonic and density logs was used for the well-toseismic tie Figure 7. There was a good correlation between the synthetic and the seismic section. The well-to-seismic tie enabled the top of the reservoir to be correlated with confidence across the seismic section.

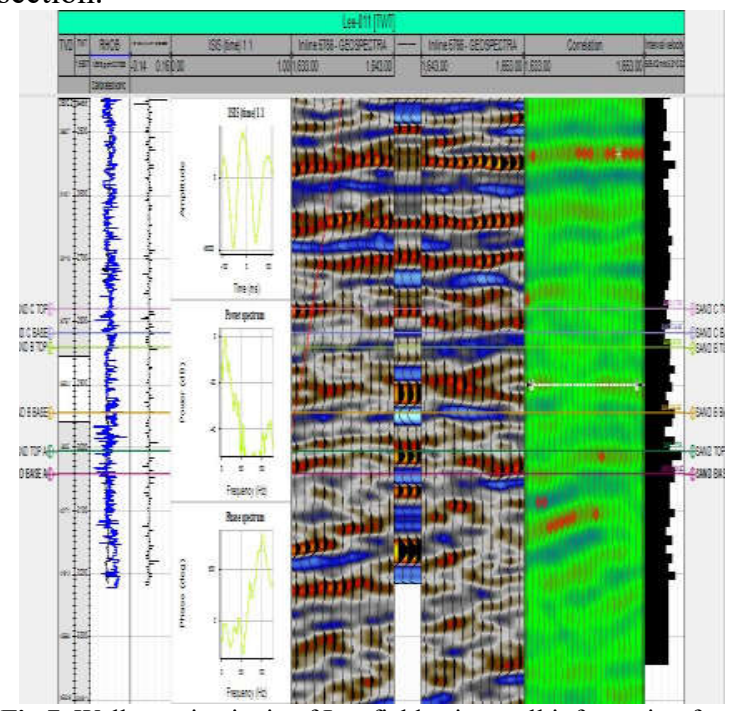

Fig 7. Well-to-seismic tie of Lee field using well information from Lee 011

The synthetic seismogram and surface seismic volume are tied at the well. Extreme left of the panel is the depth and two-way travel time followed by density and sonic logs, model acoustic impedance, wavelet/amplitude and phase spectra, surface seismic/well and synthetic seismogram, correlation panel and horizons. The time and depth structure maps were generated and this was done for the horizon picked and the time surface displayed in the map window (Figure 8). These maps show an anticlinal structure at the upper right edge of the surface which is a structural trap. The growth faults seen on the seismic section is also displayed on the surface (Emujakporue and Faluyi, 2015; Knut, 2010). After the time slice being created, a velocity model (Figure 9) was created which was used in the conversion of time to depth surface map (Figure 10). The depth structure map was then used to quantify the oil in place and also provided the basis for modelling of the petrophysical parameters (Obiora et al., 2016; Okwoli et al., 2015). The integrated time-depth structure map is displayed in Figure 11.

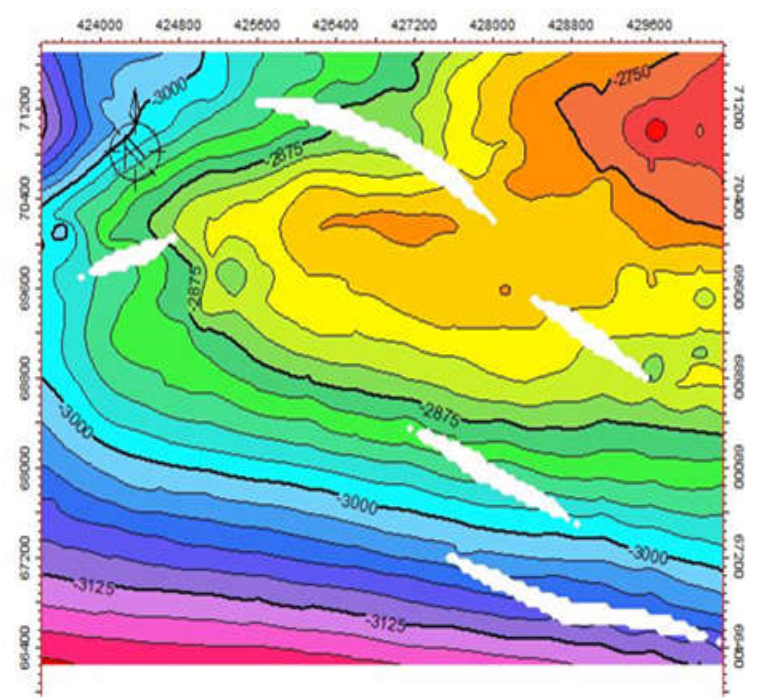

Fig 8. Time structure map for horizon 1

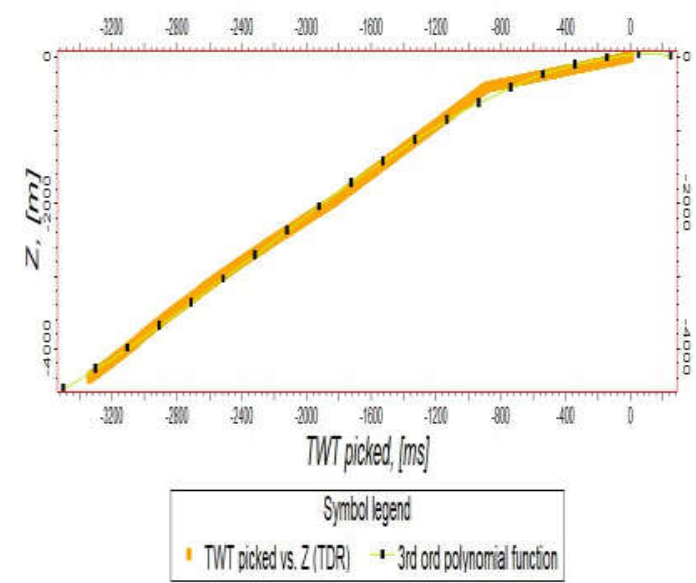

Fig 9. A modelled velocity function.

Five faults were modelled, defining their lateral shape and geometries (Figure 12). The modelled faults and the horizon structure formed the basis of the 3D structural framework. (Stacy et al., 2010; Emujakporue and Faluyi, 2015) Porosity and 
permeability are the main factors needed to be considered in reservoir characterization.

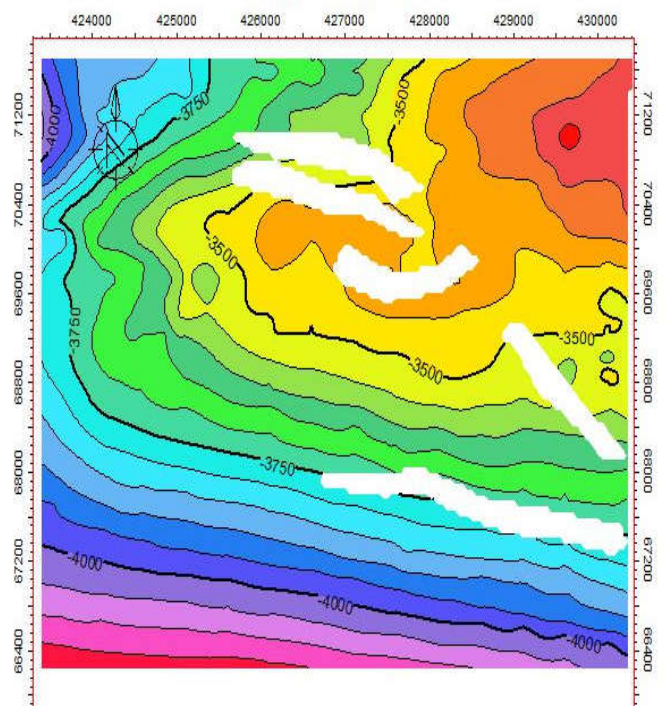

Fig 10. Depth surface for Horizon1 using the velocity model

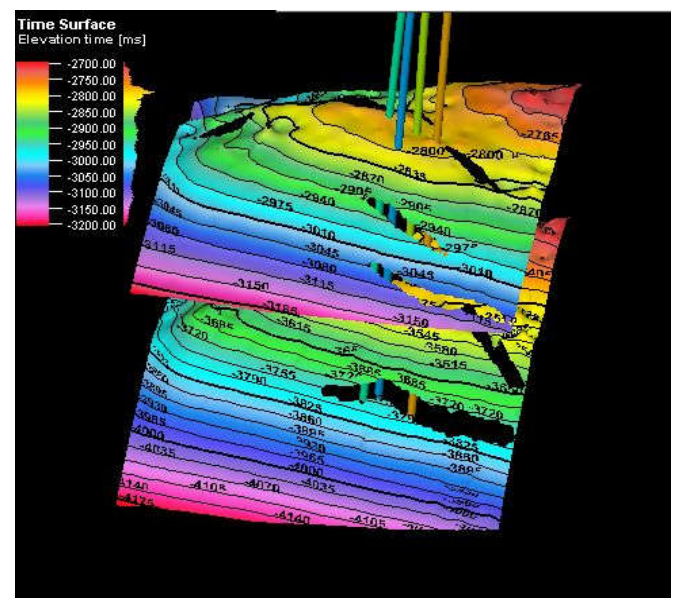

Fig 11. A display of time and depth surfaces showing all four wells of Lee field. The contour interval is $35 \mathrm{~m}$

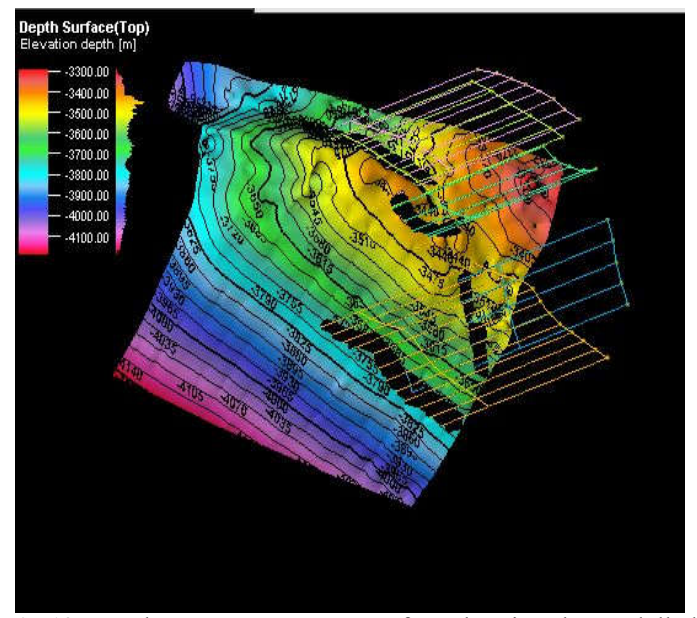

Fig 12. Depth structure map top surface showing the modelled faults

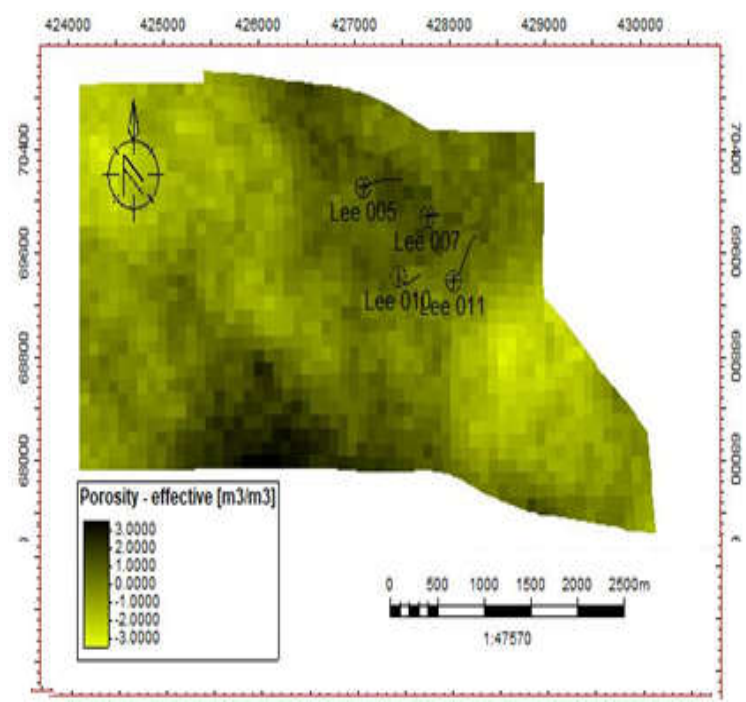

Fig 13. Effective porosity model of Lee field showing an average porosity value of over 17 percent. The location of the four wells on the field is also displayed as well as the legend.

Effective porosity is more important than total porosity because for hydrocarbon production interconnected pores are needed. Here effective porosity was calculated using total porosity and shale volume. The effective porosity model obtained revealed a range of effective porosity values ranging $14 \%$ to $21 \%$ for the Lee field. These values indicate possible hydrocarbon pore volume with well interconnected pore spaces and water-wet reservoir rocks, which permit high reservoir deliverability (Shepherd, 2009; Lyaka and Mulibo, 2018). Figure 13 represents effective porosity model of the sand A Formation. After considering effective porosity, permeability is also vital for reservoir decisions (Owolabi et al., 1994; Shepherd, 2009; Knut, 2010; Stacy et al., 2010). From analyses, these two factors revealed that the reservoir is both porous and permeable. Light blue colour indicates reservoir zones of good permeability while dark blue colour indicates reservoir zones of poor permeability. Reservoir zones are mostly represented by light blue colour. Figure 14 represents permeability model of the reservoir Sands. nNext, water saturation was considered. Water saturation is the most important petrophysical parameter after porosity and permeability because it shows the water fraction in the reservoir rock pores. This will give an estimate of hydrocarbon saturation because pores only could be filled with water or hydrocarbon. So, if one zone has very low water saturation value, that zone could be considered as hydrocarbon filled.

Figure 15 presents the model of water saturation of sand A Formation. Blue colour presents $100 \%$ water saturation, green and sky blue colours represent $50 \%$ 
to $80 \%$ water saturation, yellow colour represents $20 \%$ to $40 \%$ water saturation and orange colour represents less than $20 \%$ water saturation. Reservoir zones are mostly represented by orange and green colours in this model.

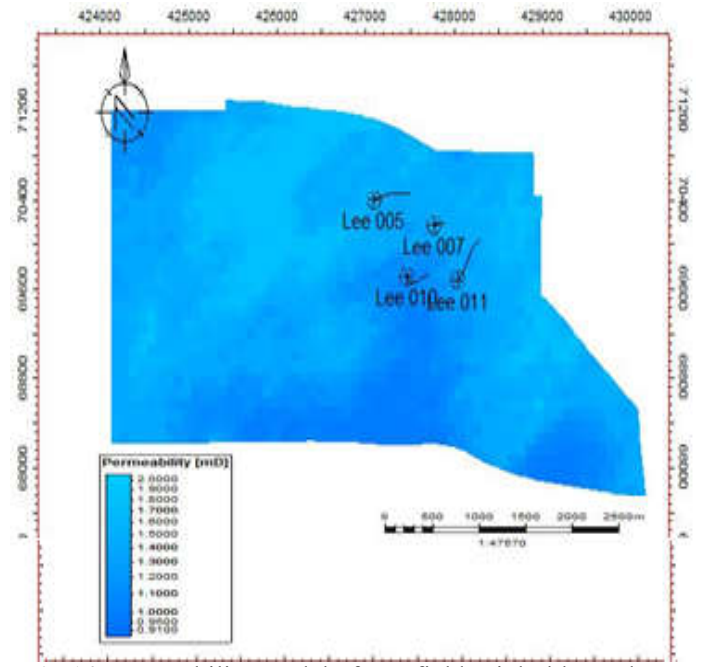

Fig 14. Permeability model of Lee field. Light blue colours indicating permeable zones. The location of the four wells on the field is also displayed.

The other important petrophysical parameter is netto-gross (NTG) ratio (Inichinbia et al., 2014c). Netto-gross estimates range from $78 \%-92 \%$. This indicates a relatively large hydrocarbon zone when compared with the shale fraction. Figure 16 presents net-to-gross ratio of Sand A Formation. The dark regions represent zones of good NTG ratio whereas the light regions indicate zones of poor to fair NTG ratio. Reservoir zones are mostly represented by the dark colours.

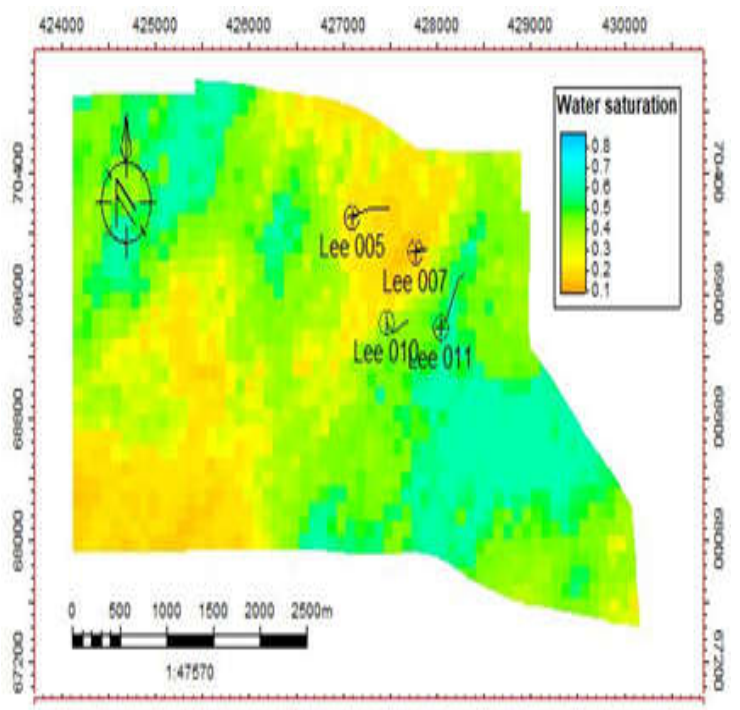

Fig 15. Water saturation model of Lee field. Reservoir zones are mostly represented by orange and green colours in this model. The location of the wells on the field is also displayed.

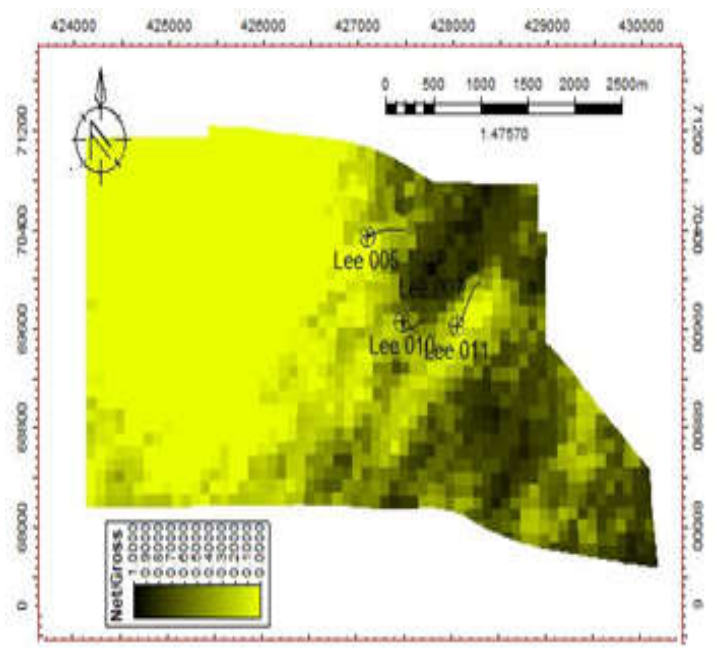

Fig 16. Net-to-Gross model of Lee field. Reservoir zones are mostly represented by the dark colours. The location of the wells on the field is displayed.

The shale volume for this field is estimated to be about $6.32 \%$ to $22.44 \%$ at the location of the wells. Figure 17 is the model of the shale volume of the field and it shows good productive zone with clean sand distribution.

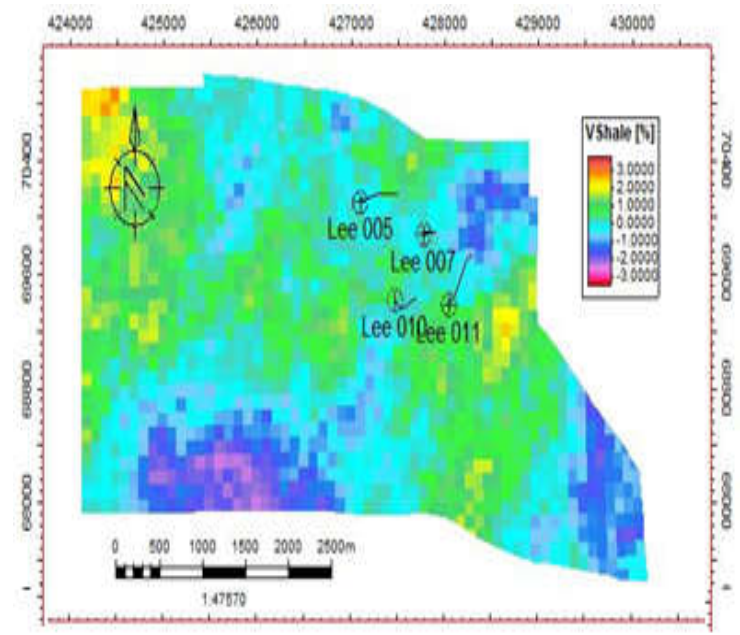

Fig 17.Volume of shale model of Lee field. The model indicates good productive zone with clean sand distribution. The location of the four wells is also indicated on the map.

Finally, all of the models can be used for reservoir decisions. Each parameter represents a different feature of the reservoir rocks and combining all of this information will give an accurate estimate for the reservoir. Average Reservoir parameters such as effective porosity $(0.17)$, gross thickness $(86 \mathrm{~m})$, hydrocarbon saturation $(0.42)$, permeability $(1215 \mathrm{md})$ and net-to-gross (0.79) were derived from petrophysical analysis. Hydrocarbon pore volume was determined from geological (area and average 
reservoir thickness) and petrophysical (porosity, netto-gross and water saturation) input (Emujakporue and Faluyi, 2015; Knut, 2010; Obiora et al., 2016; Shepherd, 2009). Figure 18 shows the reservoir extent area on the depth structure map. Table 5 shows the summary of the volumetric analysis within the Lee field with the help of appropriate formulae.

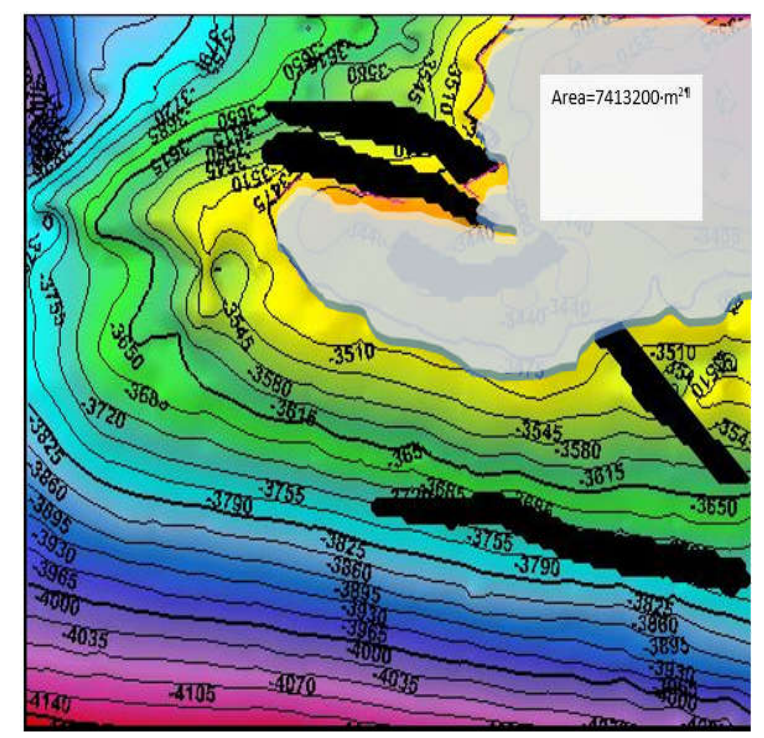

Fig 18. Depth structure contour map of Lee field as interpreted from the 3D seismic data, showing the area extent of the mapped reservoirs. The contour interval is $35 \mathrm{~m}$. the structure also showed some major faults in the study area.

One horizon was mapped for reservoir 1 which was used to form the depth structural map. The volume of hydrocarbon originally in place was estimated to be $367,180,095.08$ barrels of oil. From these results, we can infer that Lee field has exploitable potential hydrocarbon. The integration of all available data (geophysical, geological and petrophysical) has led to the building of a consistent high resolution static model of the reservoir which can serve as input into reservoir simulation model.

Table 5: Volumetric analysis of Lee field

\begin{tabular}{ll}
\hline Reservoir $(\#)$ & Reservoir 1 \\
\hline Gross thickness (m) & 93 \\
Gross thickness (ft.) & 305.11812 \\
NTG & 0.84 \\
Porosity & 0.18 \\
Hydrocarbon saturation & 0.56 \\
Area ( $\left.{ }^{2}\right)$ & $7,413,200.03$ \\
Bulk volume (bbl) & $4,336,499,604.01$ \\
Net volume (bbl) & $3,642,659,667.04$ \\
Pore volume (bbl) & $655,678,740.10$ \\
HCPV (bbl) & $367,180,095.08$ \\
\hline
\end{tabular}

Conclusion: Three hydrocarbon reservoirs were delineated and two lithofacies were identified using the Gamma ray log; and these are sand and shale. Each of the sand units extends through the field, and varies in thickness with some unit occurring at greater depth than their adjacent unit i.e. possibly an evidence of faulting. The shale layers increased with depth along with a corresponding decrease in sand layers. Fault assisted anticlinal structures serve as structural traps that prevented the leakage of hydrocarbon from the reservoirs.

Acknowledgements: The authors are thankful to all who contributed to the success of this paper.

\section{REFERENCES}

Amigun, JO; Odole, OA (2013). Petrophysical properties evaluation for reservoir characterisation of Seyi oil field (Niger-Delta). Intern. J. of Innovation and Appl. Studies, 3(3): 756-773.

Doust, H; Omatsola, E (1990). Niger Delta, in, Edwards, JD and Santogrossi, PA eds., Divergent/passive Margin Basins. American Assoc. of Petroleum Geologists (AAPG) Memoir 48: 239-248.

Emujakporue, GO; Faluyi, TO (2015). Evaluation of Hydrocarbon Volume in 'TRH' Field, Onshore Niger Delta, Nigeria. Intern. J. of Geophys. and Geochem.2(5):113-123.

Inichinbia, S; Sule P; Hamza, H; Ahmed, AI (2014)c. Estimation of net-to-gross of Among hydrocarbon field using well $\log$ and 3D seismic data. IOSR J. of Appl.Geol. and Geophy. 2(2): Ver II. 18 - 26.

Inichinbia, S; Sule, P; Ahmed, A. I., Hamza, H (2014)b. Well-to-seismic tie of Amangi hydrocarbon field of the Niger Delta of Nigeria. IOSR J. of Appl. Geol.and Geophy. 2(2) Ver I. 97 -105 .

Inichinbia, S; Sule, P; Ahmed, AI; Hamza, H; Lawal, KM (2014)a. Petrophysical Analysis of Among hydrocarbon field Fluid and Lithofacies using well $\log$ data. IOSR J. of Appl. Geol. and Geophy. 2(2): Ver I. $86-96$.

Klett, TR; Ahlbrandt, TS; Schmoker, JW; Dolton, JL (1997). Ranking of the world's oil and gas provinces by known petroleum volumes. Geol. Survey Open file Report, 97- 463.

Knut, B (2010). Petroleum Geoscience: From Sedimentary Environments to Rock Physics. Springer, New York. 
Lyaka, AL; Mulibo, GD (2018). Petrophysical Analysis of the Mpapai Well Logs in the East Pande Exploration Block, Southern Coast of Tanzania: Geological Implication on the Hydrocarbon Potential. Open J. of Geol. 8: 781 802.

Obiora, DN; Gbenga, D; Ogobiri, G (2016). Reservoir Characterization and Formation Evaluation of a "Royal Onshore Field", Southern Niger Delta using Geophysical Well Log Data. J. of Geol. Society of India, 591-600.

Okwoli, E; Obiora, DN; Adewoye, O; Chukudebelu, JU; Ezema, PO (2015). Reservoir characteriztion and volumetric analysis of Lona Field, Niger Delta, using 3-D seismic data and well log data. Petroluem and Coal, 57(2): 108-119.

Owolabi, O.O., Longjohn, T.F., Ajienka J.A. (1994). An empirical expression for permeability in unconsolidated sands of eastern Niger Delta. Journal of Petroleum Geology 17(1): 111-116.
Shepherd, M (2009). Rock and Fluid Properties. Oil field production geology. AAPG Memoir, 91: 6568.

Short, KC; Stauble, J (1967). Outline geology of the Niger Delta. AAPG Bulletin 5: 761-779.

Stacy, CA; Nathaniel, HB; Luke, EH (2010). Reservoir characterization and facies prediction within the Late Cretaceous Doe Creek Member, Valhalla field, west-central Alberta, Canada. AAPG Bulletin, 94(1): 1-25.

Ulasi, AI; Onyekuru, SO; Iwuagwu, CJ (2013). Petrophysical evaluation of uzek well using well $\log$ and core data, Offshore Depobelt, Niger Delta, Nigeria. Advances in Applied Science Research, 5(3): 2966-2991. 